\title{
GREEN ARCHITECTURE AND ENERGY EFFICIENCY AS A TRIGGER TO DESIGN CREATIVITY: A CASE STUDY TO PALEMBANG CITY LIBRARY
}

\author{
Meivirina Hanum*, Chairul Murod* \\ *)Program Study of Architecture, Faculty of Engineering UNSRI, Indonesia \\ e-mail: meivihanum@gmail.com
}

\begin{abstract}
Facts said that the main consumer to energy is a building; or high and big scale ones. This sector needs almost $100 \%$ of artificial energy. Dependability to this artificial energy results in environment destruction: energy's exploitation and global warming. This conditional was triggering architects to be wiser and be more creative in designing to the energy efficiency concept.

Green Architecture is one of the answers to this challenge in architecture design process. The exploration to architecture design concepts that based on energy efficiency became an alternative and also demands to professional architects this era.

Palembang City Library design - which its 60-70\% area is a swamp - was using stage concept to minimize the swamp piling up.
\end{abstract}

Keywords: green architecture, energy efficiency, creative designing, innovative material technology

\begin{abstract}
ABSTRAK
Fakta mengungkapkan bahwa konsumen utama dari energi adalah bangunan; atau skala yang tinggi dan besar. Sektor ini membutuhkan hampir 100\% energi buatan. Ketergantungan dengan energi buatan ini menghasilkan kerusakan lingkungan: eksploitasi energi dan pemanasan global. Kondisi ini memicu arsitek untuk lebih bijaksana dan lebih kreatif dalam merancang konsep efisiensi energi.

Arsitektur Hijau merupakan salah satu jawaban atas tantangan ini dalam proses desain arsitektur. Eksplorasi konsep desain arsitektur yang didasarkan pada efisiensi energi menjadi alternatif dan juga tuntutan untuk arsitek profesional era ini. Desain perpustakaan Kota Palembang - yang wilayahnya 60-70\% adalah rawamenggunakan konsep panggung untuk meminimalkan rawa menumpuk.
\end{abstract}

Kata kunci: arsitektur hijau, efisiensi energi, kreatif desain, inovatif teknologi material 


\section{INTRODUCTION}

Compared to other sectors, architecture is the highest one that consumed energy, caused of almost $100 \%$ its progress and result using artificial energy. As cited from Krishan (2001) (Figure 1).

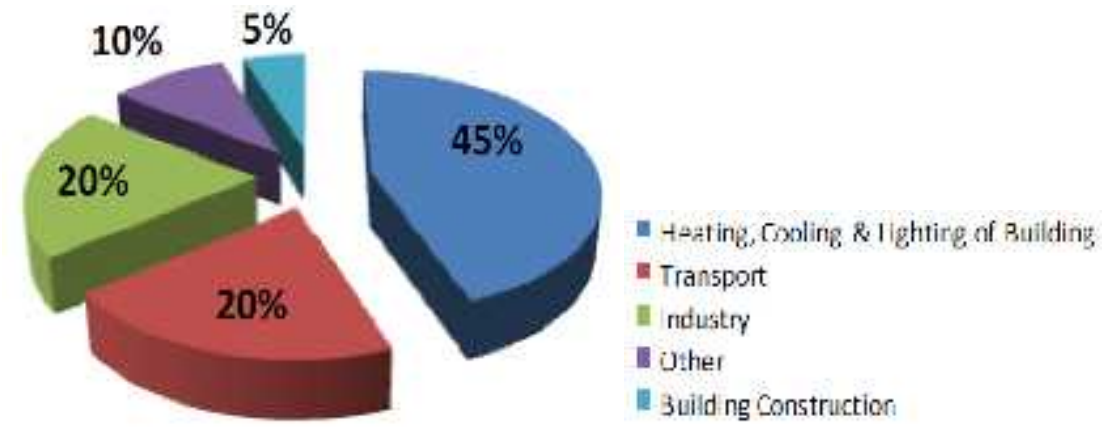

Figure 1. Global Energy Use (1986)

Consumption by Sector

Source: Krishan, 2001

This is also supported by Roy (2001) from Architecture Department Jadavpur University, Golgota, India (Figure 2).

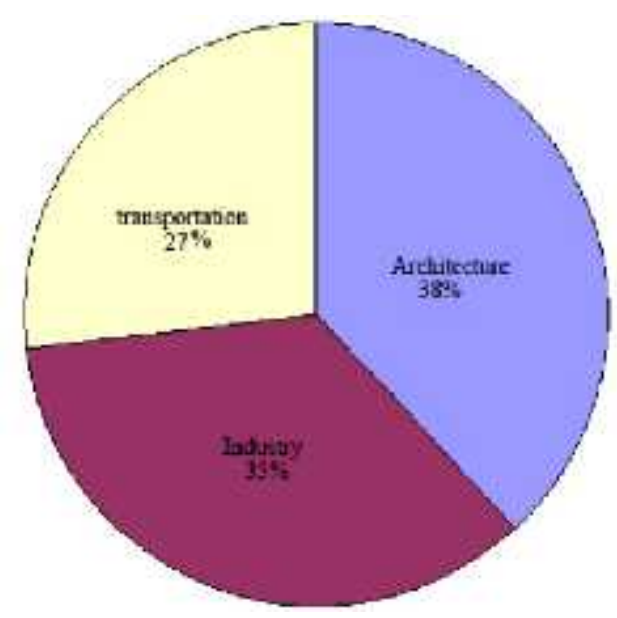

Figure 2.The Percentage of Energy Consumption by Different Sector Source:Roy, 2001

If this is continued, enough to destruct the earth: exploitation of earth resources and energy and also global warming. And could be worse when architects only considering their design ambition, not caring the environment. That's why, exploration to the architecture designing based on Green Architecture concept, now 
not only become an alternative but also a demand to professional architects in this era. Green Architecture concept which is the final purpose is saving energy on building, now become an answer to these energy problems, and become a challenge in architecture design.

Palembang City Library in its design process approach not only fulfills its room needs but also explores its site form, building existing, and building positioning to respond its area which $60-70 \%$ of it is a permanent swamp. This condition covered by stage concept and suspended floor. Combination of active and passive green architecture concepts applied to depress the energy consumption, like optimizing its structure and façade to natural lighting and circulation. The design process of this building is definitely a challenge to its architect creativity.

\section{THEORY / RESEARCH METHODS}

\section{Green Architecture}

The term green architecture means 'building and structure design philosophy that aims at minimal use of non-renewable and/or polluting materials and resources in construction and use of a facility'. This philosophy of architecture advocates sustainable energy sources, the conservation of energy, the reuse and safety of building materials, and the siting of a building with consideration of its impact on the environment (Wines, 2008).

This term also means architecture in which the design is focused on making a building energy-efficient, so as to reduce its energy consumption, water consumption, operating costs, and environmental impact. Such efficiencies include the maximal use of natural lighting, low-e glass, solar electric systems, energy-efficient lighting systems, and energy-efficient ventilation systems including the use of the chimney effect, and newer sustainable materials and techniques that minimize heat loss in buildings (Hill, 2003).

Also, definition of green architecture by Craven (2003) said that green architecture or green design is an approach to building that minimizes harmful effects on human health and the environment. The "green" architect or designer attempts to safe guard air, water, and earth by choosing eco-friendly building materials and construction practices. Green Architecture or green design is also can be defined as an approach to a building that reduces waste of energy, water and materials used during construction.

\section{Green Architecture in Summary}

Green architecture in principal is an architecture that prefers utilizing renewable materials - which are able to be reused, reduced, and recycled'- from nature to using non-renewable ones.

Green architecture also noted on its design process that calculating site management, waste management, building orientation to environment and sunlight timing management, and wind circulation management. More importantly, green archi- 
tecture also considering social, culture, environment, and user aspects. Green architecture is a challenge to more creative, innovative, and efficient designing.

\section{Public Library}

\section{Definition in Architecture Context}

Public libraries are function to serve the needs of information of a diverse service population including small children, students, professionals, and the elderly.

Some design criteria should meet these needs i.e. are easy access into the building, adequate lighting, large-print media, etc. Else yet important is factors for keeping the library collections safe like one stated in HVAC Design Criteria for Museum \& Library. These criteria of course, need a lot of energy.

\section{HVAC Design Criteria for Museum \& Library}

HVAC design is a specialized control to the environment in which museum and library collections are stored. Factors that can affect stored collections and typical museum/library refer to HVAC design guidelines follow:

1. Temperature

When temperature rises to approximately $14^{\circ} \mathrm{F}$, the chance of deterioration rate of organic products in museum \& library environments get doubled.

Then temperature should be maintained between $65^{\circ}$ and $75^{\circ} \mathrm{F}$ throughout the year; seasonal fluctuations between the two extremes are allowed, but daily fluctuations should be $\pm 5^{\circ} \mathrm{F}$.

2. Humidity

We know that humidity usually associated with an increased of mold growth and other forms of bio deterioration. Besides that the effects are furniture joints loosen, paint-to-chip cause, degradative chemical reactions promotion, metals corrode, dyes and inks fade, and even glass and mineral collections damage.

Based on HVAC, Relative Humidity $(\mathrm{RH})$ levels should be maintained between $40 \%$ and $55 \%$ throughout the year; seasonal fluctuations allowance between the two extremes; and daily fluctuations held to $\pm 3 \%$ (Carrow, 1995).

\section{Green Architecture: Passive and Active Solar Building Design}

\section{Passive-Solar Building Design}

The spontaneous warming effect resulting from the absorption of solar radiation is called 'Passive-Solar Heating'. When temperature rises, this induces leads to heat flow from the affected surface to other surface and indoor air, as well as to processes of heat storage within the building structure. This heat storage modulates the excess and deficit in solar gain over the daily cycle, and is a critical design consideration. Passive solar heating relies on the design of windows, clerestories, roof lights, glazed walls and roofs. 
'Passive-Solar Cooling' is the dissipation of excess heat by natural process. This depends on two conditions: the availability of a heat sink which is at a lower temperature than indoor air, and the promotion of heat transfer towards the sink (Krishan and Nick, 2001). 'Passive-Solar Lighting' techniques enhance taking advantage of natural illumination for interiors, and so reduce reliance on artificial lighting systems(Wikipedia, 2013).

In passive solar building design context, windows, walls, and floors are made to collect, store, and distribute solar energy in the form of heat in the winter and reject solar heat in the summer. This is knowingly called climatic design. Because unlike active solar heating systems, it doesn't involve the use of mechanical and electrical devices at all (Wikipedia, 2013).

There are no additional mechanical or electrical devices to deliver heat or electrical energy, no additional fuel or utility costs, and no added environmental impacts in passive-solar building design. For this reason, many people think that passive solar technology is superior to active solar technology (Webster, 2008).

\section{Active-Solar Building Design}

Meanwhile, active solar technologies are contributed to convert solar energy into another more useful form of energy. This could be a conversion to heat or electrical energy. In the building this energy would be used for heating, cooling, or off-setting other energy use or costs. Active-solar usually uses electrical or mechanical equipment for this conversion (Wikipedia, 2013).

In summary, active-solar systems use external sources of energy to power blowers, pumps, and other types of equipment to collect, store and then convert solar energy. Once energy from the sun is absorbed, it stored for later use. Small systems are ones that used to furnish electricity for heating and cooling systems in homes and other buildings, while large systems can furnish power for entire communities (Surya Urza, 2013).Active-solar system uses the sun's irradiance or radiation (the sun's rays) then converts it to electricity to power systems in your home (Allcot, 2011).

\section{Research Methods}

Method used in this research is desk evaluation to two areas: design analysis and HVAC analysis. The Palembang City Library design desk evaluation based on 'Green Architecture Theories' from Brenda and Vale (1991), which stated its five basic principles: 'Conserving Energy', 'Working with Climate', 'Respect for Site', 'Respect for User', 'Limiting New Resources', and 'Holistic'.

Each of these basic principles used as analyzing form respond to climate and environment: site, orientation to sunlight cycle, wind direction and shading, and also ornaments and materials choosing relevant to heat absorption reflection level and heat reduction. This design analysis only concentrated to the building design output, not the analytical calculation.

For HVAC (Heating, Ventilation, and Air Conditioning), analysis was done by evaluating it from passive and active-solar design principles. It's focused on form 
- the site as well as the façade - that responsive to climate. Hypothetically, this refer to green architecture concept building design process will generate the architect creativity.

\section{RESULTS AND DISCUSSION}

\section{Palembang City Library}

Palembang City Library is one in same level with Regional Library. It is only the ownership and management that different it from Regional, which is in City/Province government. This library located on intersection of J1. Demang Lebar Daun and Jl. Ogan (Figure 3).

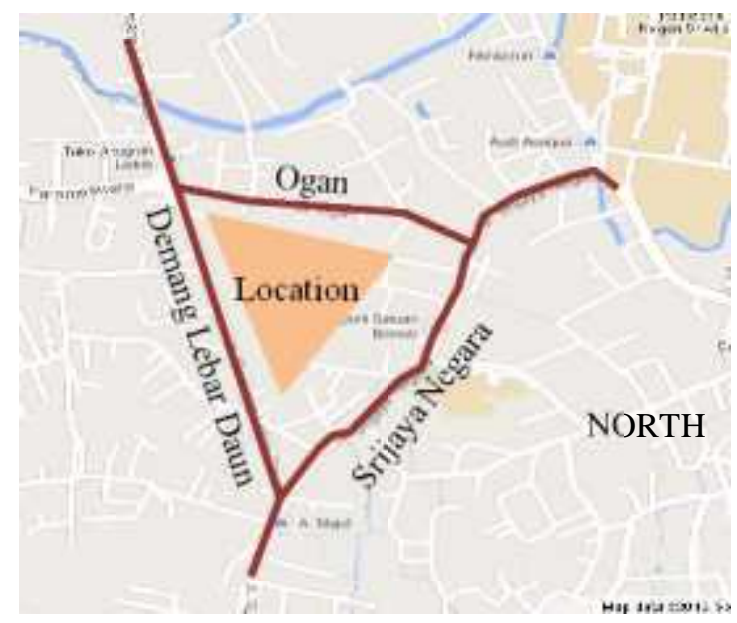

Figure 3.The Palembang City Library Location Source: Palembang Google Map, 2013

This design was used as a case study to energy-efficient building (Figure 4). More as preliminary study or pre-research that hopefully could be generated as inspiration and source to other public libraries in South Sumatera (BAPPEDA, 2005). 


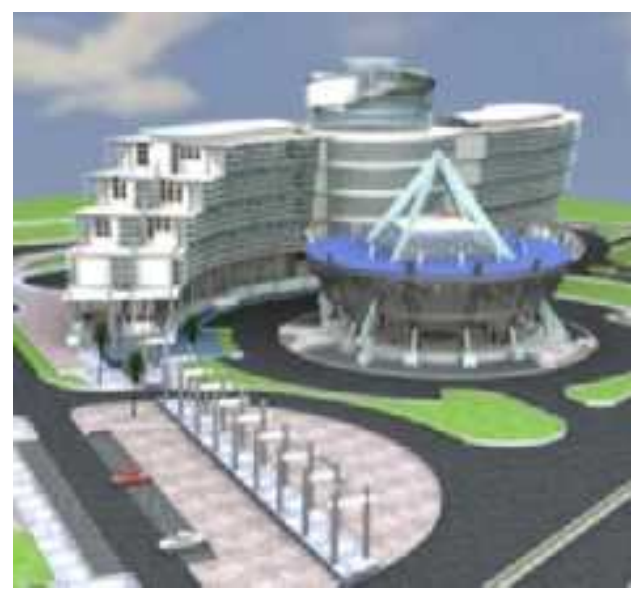

Figure 4.The Palembang City Library Source: BAPPEDA, 2005

This library planned to be 6-floors building, with approximately 11.000 square meters, $40 \% K D B$, and 100 meter $G S B$. Existing site approximately 25.000 square meters, wet land topography which $50-60 \%$ of it is permanent swamp (Figure 5).

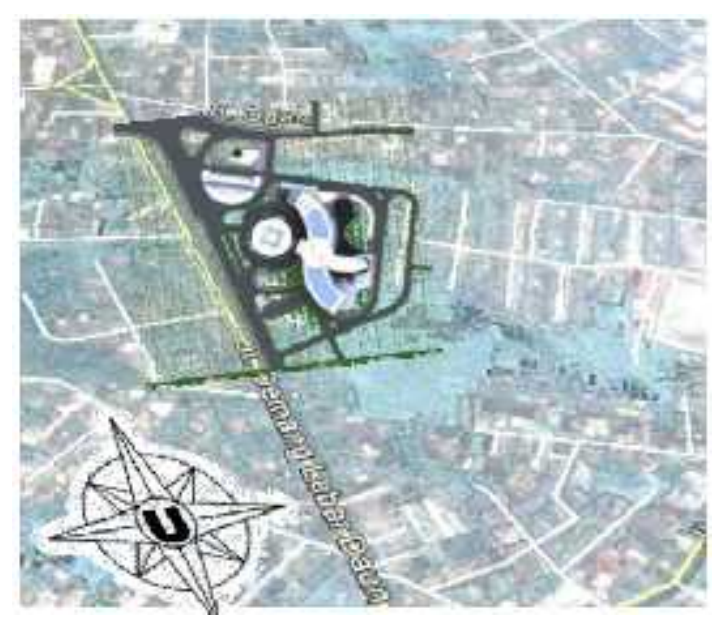

Figure 5.The Palembang City Library Existing Source: Google Earth, 2013

Climatology analysis: highest-temperature in 33 Celsius degree, lowesttemperature in 23 Celsius degree, wind speed in 30 kilometers per hour to southeast, and humidity at 52-96\% (Badan Meteorologi, Klimatologi dan Geofisika, 2008).

Table 1 below is Man deep (2011) research entitled 'Cumulative Distribution of Rainfall Data for Tropical Countries', which is taking cities all over the world as a sample, and one of it is Palembang. This information - along with sun light cycle 
in area information data - used for analyzing building positioning, form, and orientation of Palembang City Library.

Table 1. Description of Regions, Climate, Location, and Annual Rainfall (mm) for the 24 Locations

\begin{tabular}{|c|c|c|c|c|c|c|}
\hline Country & Regions & State & Climate & $\begin{array}{c}\text { Latitude } \\
(-)\end{array}$ & $\begin{array}{l}\text { Longi- } \\
\text { tude (-) }\end{array}$ & $\begin{array}{c}\text { Average An- } \\
\text { nual rainfall } \\
(\mathrm{mm})\end{array}$ \\
\hline Malaysia & $\begin{array}{l}\text { North } \\
\text { Peninsu- } \\
\text { lar }\end{array}$ & $\begin{array}{l}\text { Alor star } \\
\text { Baling } \\
\text { Langkawi } \\
\text { Penang } \\
\text { Ipoh }\end{array}$ & $\begin{array}{l}\text { Tropical } \\
\text { Tropical } \\
\text { Tropical } \\
\text { Tropical } \\
\text { Tropical }\end{array}$ & $\begin{array}{l}6.2 \\
5.7 \\
6.23 \\
5 \\
4.57 \\
\end{array}$ & $\begin{array}{l}100.4 \\
100.9 \\
99.7 \\
100 \\
101.1\end{array}$ & $\begin{array}{l}1990.5 \\
2183.2 \\
2427.9 \\
2485.7 \\
2427.9\end{array}$ \\
\hline Nigeria & $\begin{array}{l}\text { South } \\
\text { West }\end{array}$ & $\begin{array}{l}\text { Lagos } \\
\text { Benin } \\
\text { Ile-ife } \\
\text { Warri } \\
\text { Ibadan }\end{array}$ & $\begin{array}{l}\text { Tropical wet } \\
\text { Tropical wet } \\
\text { Tropical wet } \\
\text { Tropical wet } \\
\text { Tropical wet }\end{array}$ & $\begin{array}{l}6.58 \\
6.22 \\
7.42 \\
5.52 \\
7.21\end{array}$ & $\begin{array}{l}3.3 \\
5.39 \\
4.31 \\
5.7 \\
4.01\end{array}$ & $\begin{array}{l}1538 \\
1948 \\
1245 \\
2776.4 \\
1245\end{array}$ \\
\hline Kenya & $\begin{array}{l}\text { West } \\
\text { Province }\end{array}$ & $\begin{array}{l}\text { Eldoret } \\
\text { Kisumu } \\
\text { Nairobi } \\
\text { Kitale } \\
\text { Kericho }\end{array}$ & $\begin{array}{l}\text { Sub tropical } \\
\text { Tropical wet } \\
\text { Sub tropical } \\
\text { Tropical wet } \\
\text { Tropical wet }\end{array}$ & $\begin{array}{l}0.53 \\
0.10 \mathrm{~S} \\
1.32 \mathrm{~S} \\
1.02 \\
0.37 \mathrm{~S}\end{array}$ & $\begin{array}{l}35.2 \\
34.7 \\
36.79 \\
35 \\
35.29\end{array}$ & $\begin{array}{l}1062 \\
1388 \\
1043.2 \\
1185.6 \\
1751.9\end{array}$ \\
\hline Indonesia & $\begin{array}{l}\text { Peninsu- } \\
\text { lar } \mathrm{Su}- \\
\text { matera }\end{array}$ & $\begin{array}{l}\text { Medan } \\
\text { Padang } \\
\text { Bandar Aceh } \\
\text { Riau } \\
\text { Palembang }\end{array}$ & $\begin{array}{l}\text { Tropical } \\
\text { Tropical } \\
\text { Tropical } \\
\text { Tropical } \\
\text { Tropical }\end{array}$ & $\begin{array}{l}3.57 \\
0.88 \mathrm{~S} \\
5.52 \\
1.05 \mathrm{~S} \\
2.90 \mathrm{~S}\end{array}$ & $\begin{array}{l}98.6 \\
100.3 \\
95.4 \\
103.4 \\
104.7\end{array}$ & $\begin{array}{l}2263 \\
4305.3 \\
3620.3 \\
2344 \\
2474.6\end{array}$ \\
\hline PNG & $\begin{array}{l}\text { North } \\
\text { Region }\end{array}$ & $\begin{array}{l}\text { Lae } \\
\text { Madang } \\
\text { Kavieng } \\
\text { Vanimo }\end{array}$ & $\begin{array}{l}\text { Tropical wet } \\
\text { Tropical wet } \\
\text { Tropical wet } \\
\text { Tropical wet }\end{array}$ & $\begin{array}{l}6.73 \mathrm{~S} \\
5.22 \mathrm{~S} \\
2.69 \\
2.27 \mathrm{~S}\end{array}$ & $\begin{array}{l}147 \\
145.8 \\
150.29 \\
141.7\end{array}$ & $\begin{array}{l}4579.4 \\
3498.9 \\
2984.7 \\
2792.9\end{array}$ \\
\hline
\end{tabular}

While 'Sun path Diagram' see sundial and latitude position of the library (Figure 6 and 7). And help giving a better graph of climate around (Figure 8). 


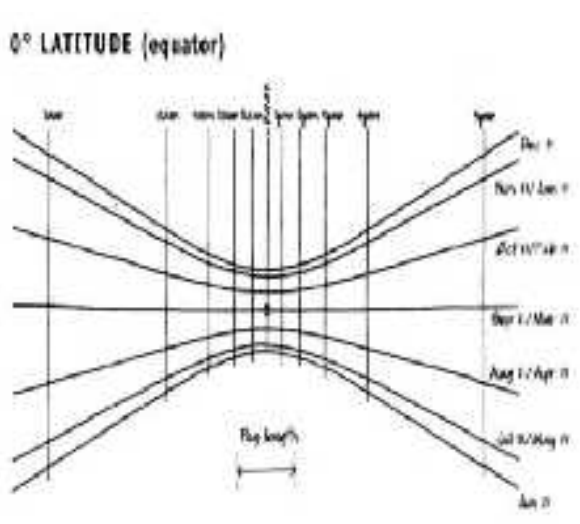

Goudial, $v^{\prime}$ hatitude Conutori

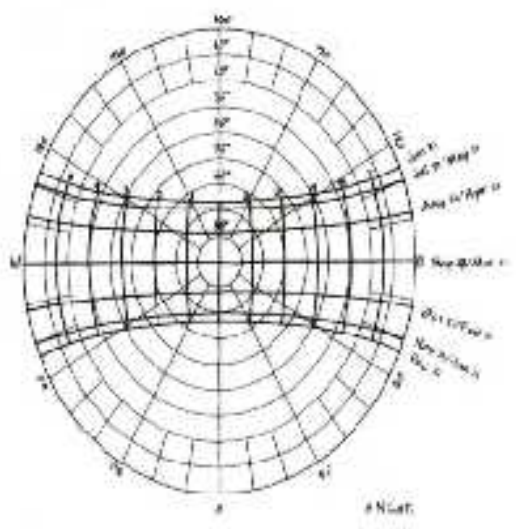

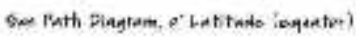

Figure 6 and 7. The Palembang City Library Sundial Position Source: Brown and De Kay, 2001

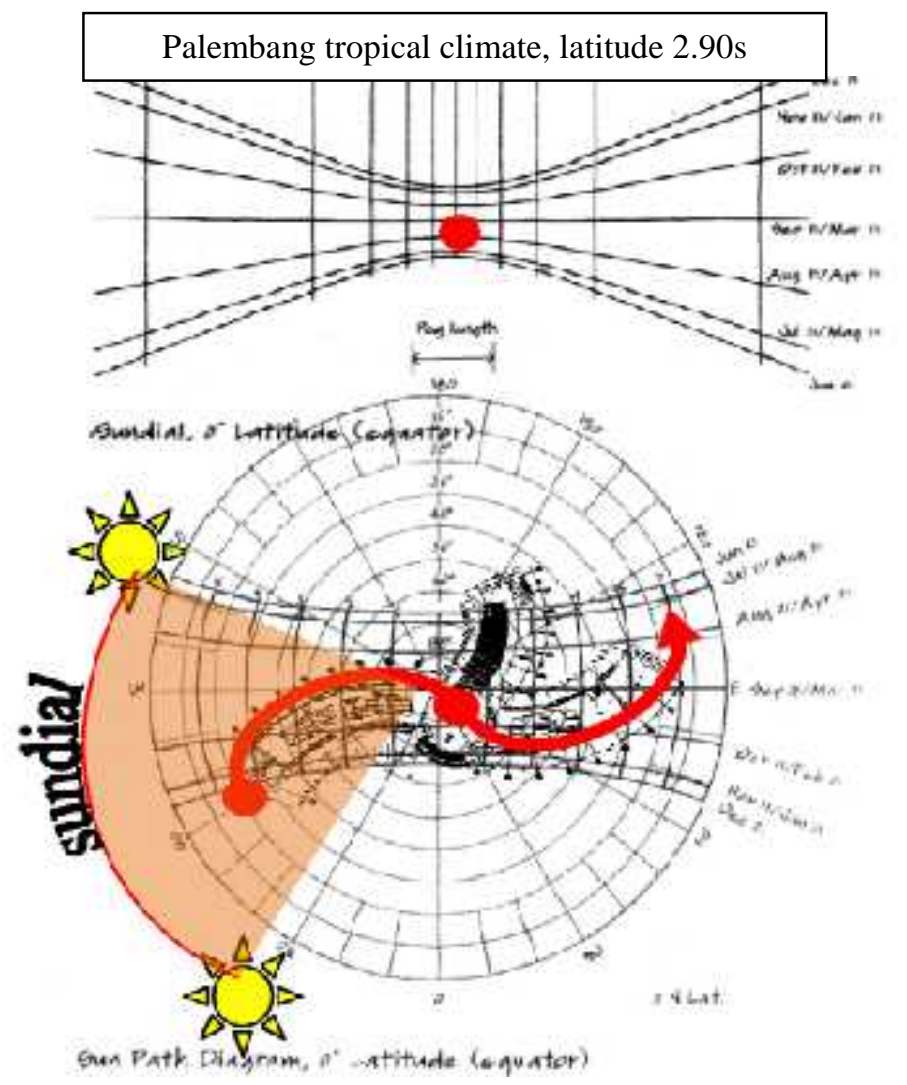

Figure8.The Palembang City Library Climate

Based on Sundial and Latitude Position Source: Brown and DeKay, 2001 


\section{Design Analysis based on Brenda and Robert Vale Green Architecture Theory}

\section{Conserving Energy and Working with Climate}

This theory said that design creativity seen on how architect is able to modify the building structure and form so it's adjusted to climate and environment; not in contrary. The pressure point is on nature resources itself, how far it could be optimized to reduce the electricity or artificial energy use.

As an example, optimize the solar potency as energy resource, or explore the building form by means its circulations working best so air conditioner no longer needed. This could be done by applying passive-solar or active-solar concept, or both:

1. Building Form and Orientation to Solar Cycle

In case to optimize solar exposure, this Palembang City Library was designed in curve form and 'mirror' on most of it (Figure 9). This dynamic curve mass form gives benefit a dynamic solar-receiving-area as well: the inside curve to minimize midday-solar exposure, and the outside curve to maximize the early and late daysolar exposure. While the mirror reflects the solar back and minimize the unwanted heats (Florida International University, 2013).

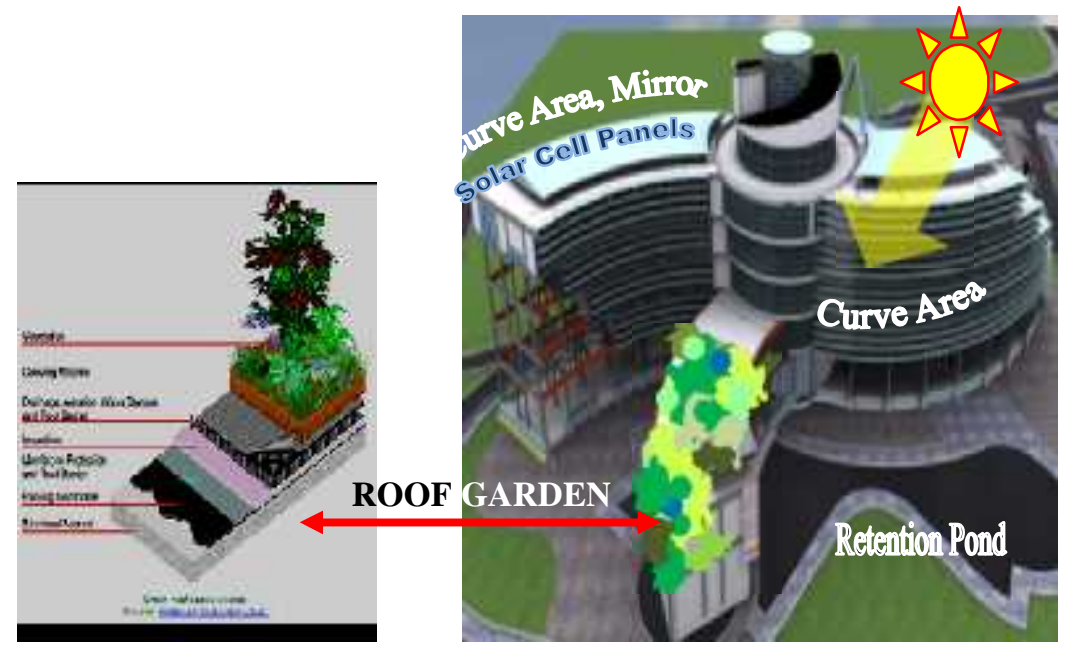

Figure 9.The Palembang City Library Form and Orientation to Solar Cycle Source: Hanum, 2005

This dynamic form also gives a best-working circulation, so the heats automatically reduced (Figure 10 and 11). Besides the form, dynamic floor construction, vegetation - like roof garden, and water areas - retention pool in ground floor gives contribution to the circulation as well. 


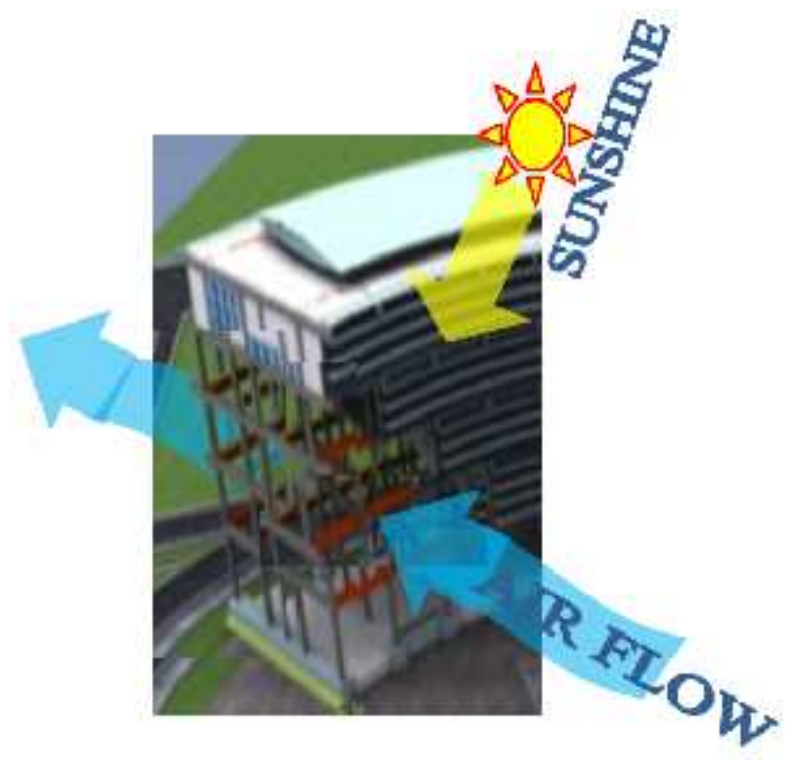

Figure 10.The Palembang City Library Circulation System Source: Hanum, 2005

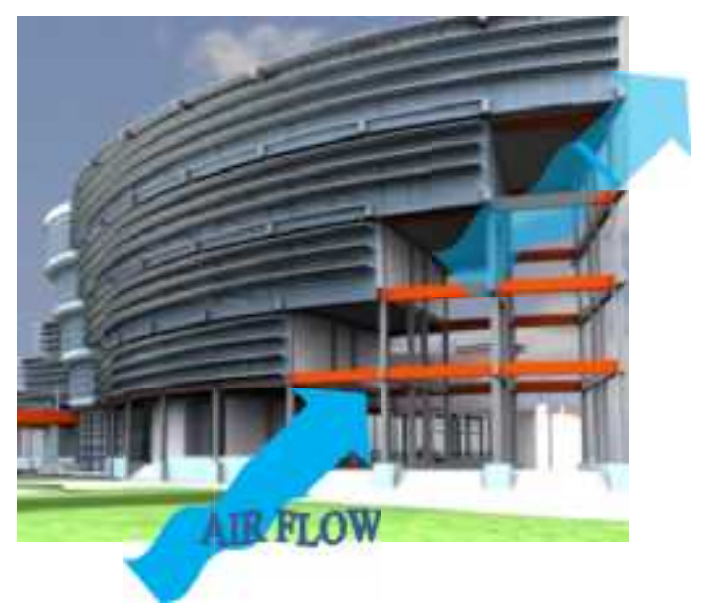

Figure 11.The Palembang City Library Dynamic Floor Construction Source :Hanum, 2005

2. Hybrid Design: Integrated Passive-Active Design

Beside the passive-concepts application above, this library also uses active-solar design. First, it uses 'Photovoltaic' or more popular as solar cells above the roof floor to gain the thermal resource for electricity and ornament at once (Figure 12). 


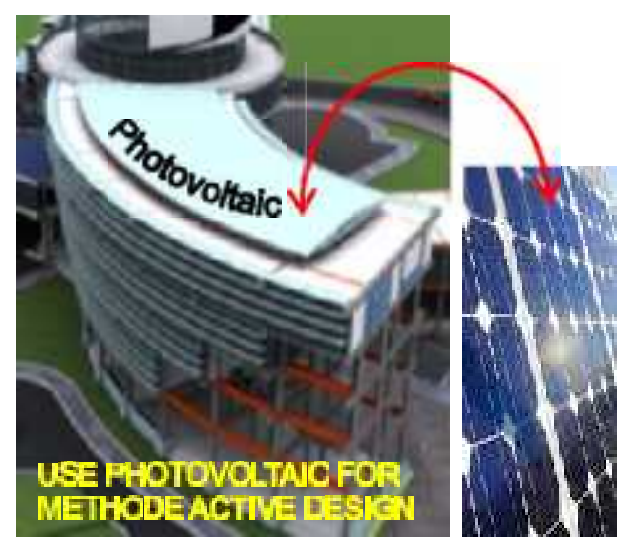

Figure 12.The Palembang City Library Photovoltaic

Source: Hanum, 2005

Second, it's finished with "sunscreen" and 'sunshade" (Figure 13). Sunscreen on windows functioned as automatic-light intensity-controller; guarantee the rooms get enough natural lighting and heat. While sunshade contributes on protecting building skin from over-heating, it also helps diffusing the natural lights, so could be used as day-lighting and minimize the use of artificial lights.

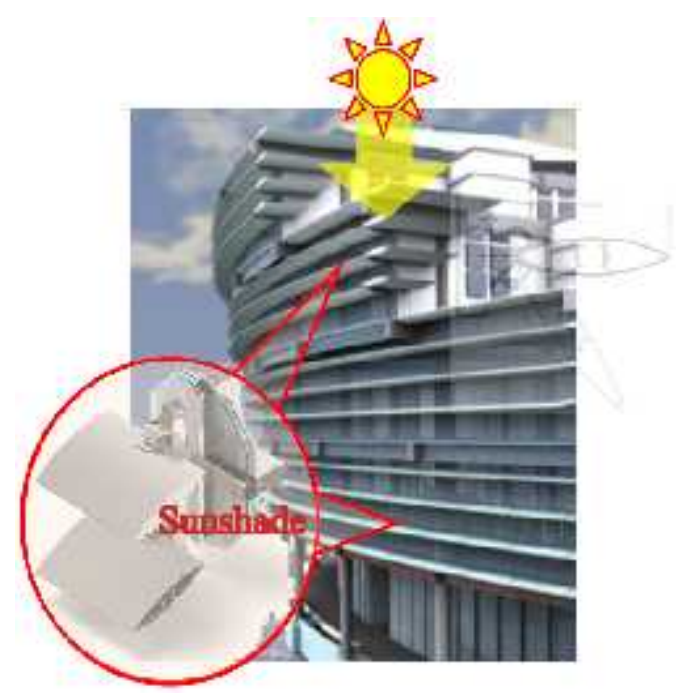

Figure 13.The Palembang City Library

Sunscreen and Sunshade Source: Hanum, 2005 


\section{Respect for Site \& Respect for User}

Besides the building form and orientation, this library structure also responds to site topography that almost of it is swamp. These respect-for-site implementations are: 1. Hold about $40 \%$ parts of the swamp areas for retentions and green-opened-areas;

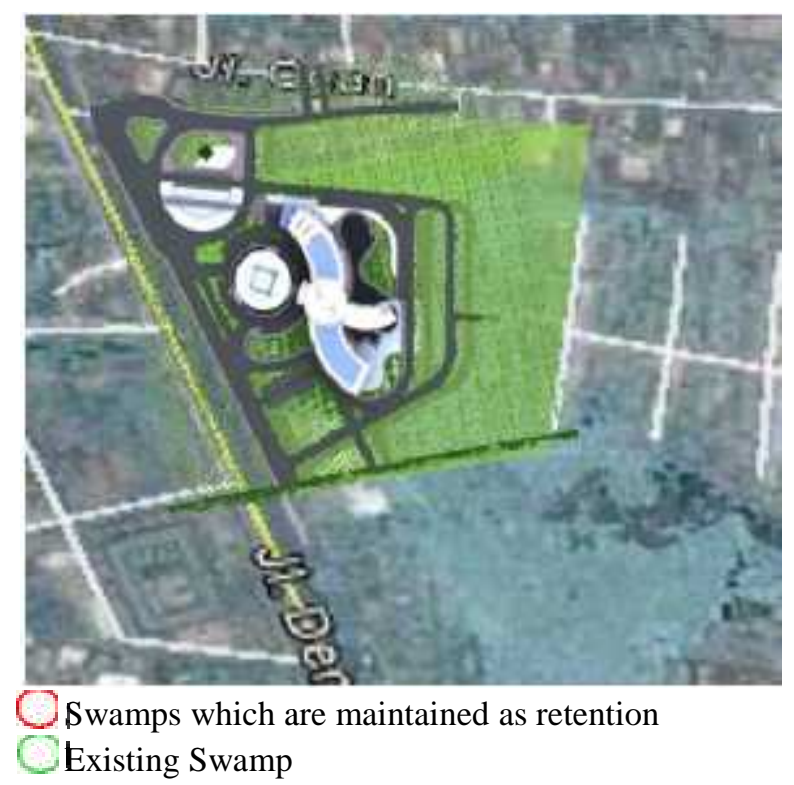

Figure 14. The Palembang City Library Existing Source: Hanum, 2005

2. Its mass that thin and vertical unified to environment and climate;

3. Its floor structure that "suspended" not 'slap-on-ground," so it supports 'the stageconcept' and accommodates the lowland site (Figure 15).

Respect-for-user implementations could be done by exploring local identity. This library adopted "stage" concept or local Palembang identity, "rumah limas". This concept of course respects the social-culture of Palembang. 


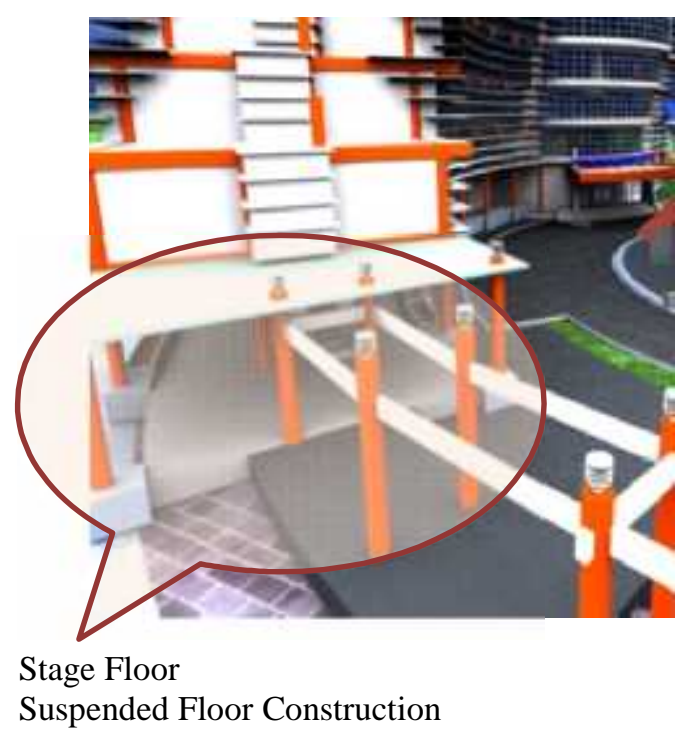

Figure 15.The Palembang City Library Suspended Floor and Stage Construction Source: Hanum, 2005

\section{Limiting New Resources}

This effort would be achieved by:

1. Optimizing already-in-stock materials and minimize the new ones;

2. Using biodegraded and reused materials;

3. Reducing non-renewable natural resources and energy use;

4. Recycling the possible materials.

\section{Holistic}

As seen above, all of these green architecture principles cannot be applied separately, but supports one-another (Brenda and Vale, 1991). 


\section{Result By Table}

Table 2.The Study Result

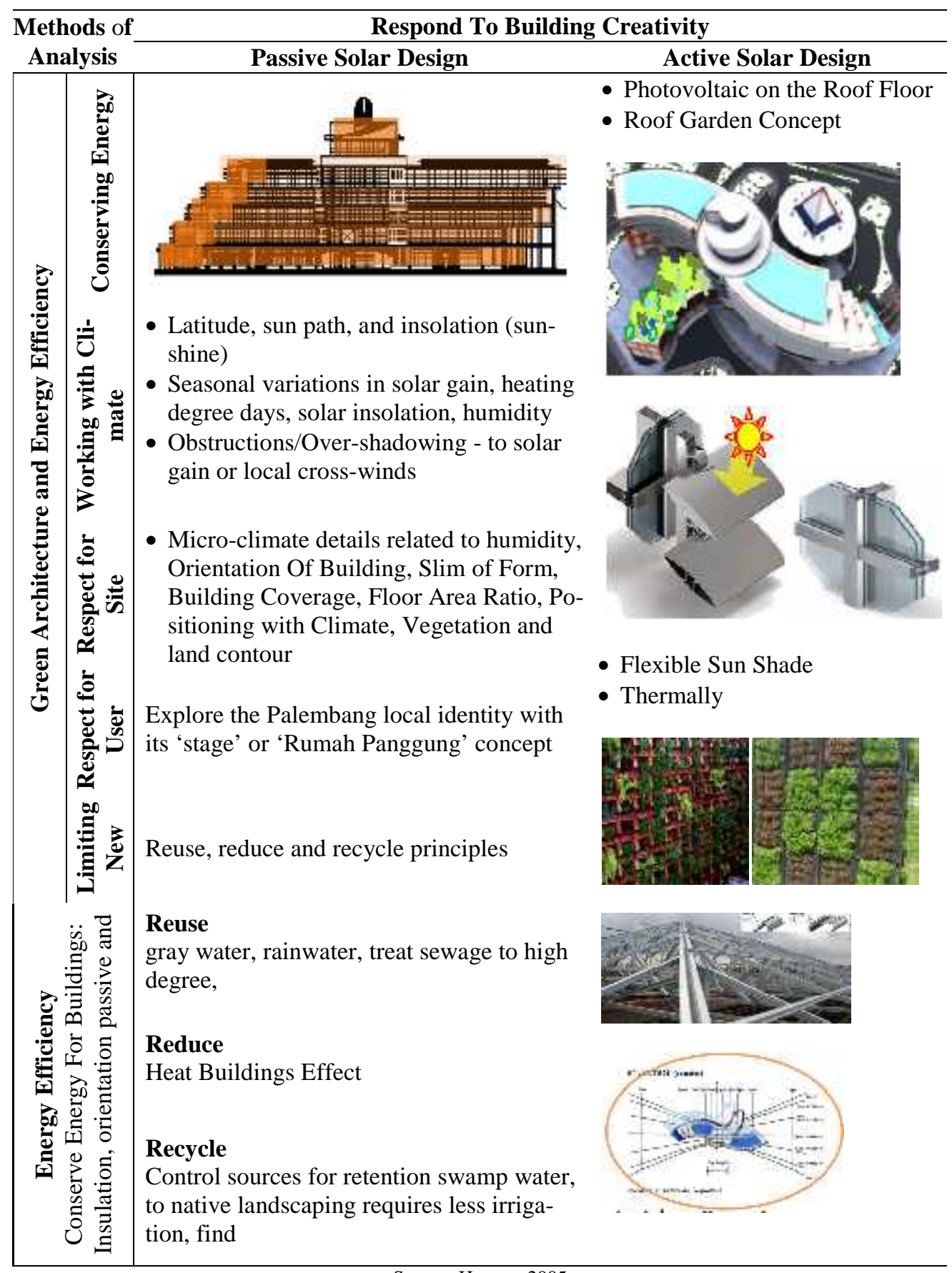

Source: Hanum, 2005 


\section{CONCLUSIONS}

A variety of guidelines for sensitive climatic building design were developed including the use of shaded space and sun control, passive cooling through cross ventilation and the use of lightweight exterior construction of low thermal capacity to avoid the accumulation and re-radiation of heat. A key objective of the Master Plan was that all new buildings comply with the north east/south west orientation and be designed to produce comfortable interior environments with minimal interference from artificial climate controls.

As a result of the increased interest in green building concepts and practices, a number of organizations have developed standards, codes and rating systems that let government regulators, building professionals and consumers embrace green building with confidence. In some cases, codes are written so local governments can adopt them as by laws to reduce the local environmental impact of buildings.

As these demands and challenges come around, there is no way that architects could run away. The only way left is to face these "limitation". And the only way to work well on limitation is by being 'creative'. The technologies are now provided to help the concept realized. There were already so many examples. One of it is Palembang City Library.

Drove by a challenge that almost of its existing site were swamps and a will to embrace it well in to uniquely-local identity-reflection public space, the architect applied green architecture concept creatively. It contents shaded space and sun control, passive and active cooling design ventilation, and the use of lightweight exterior construction as architectural ornament.

It combined passive-active architecture concept very well, along with respect to Mother Nature, as these are all the holistic components of green architecture by Brenda and Robert Vale. It considers respect for environments with minimal interference from artificial climate controls and efficiency energy basic concept by means, orientation of building, its slim form, building coverage, floor area ratio, and its positioning just adjusting the climate, vegetation, land contour, and solar energy exposure.

Obviously nature is the truly inspiring teacher. It derives architecture in to the next level. Like concluded by Wines (2008):

The aesthetic and green design that ensemble of real goods has to successfully achieve the client's objectives; the site plan should maximize elements of beauty, serenity, and spirituality; this should be a sanctuary and a testament to sustainable building practice, energy systems, living, agriculture, and community.

\section{REFERENCES}

Allcot, D. (2011), What the Difference between An Active and Passive Solar System, <http://www.ecooutfitters.net/blog/2011/10/whats-the-differencebetween-an-active-and-passive-solar-system/>. 
Badan Meteorologi, Klimatologi dan Geofisika (2008), Prakiraan Cuaca Propinsi Sumatera Selatan, <http://meteo.bmkg.go.id/-prakiraan/propinsi/08>.

BAPPEDA Project APBD (2005), Detail Engineering Design - DED Perpustakaan Kota Palembang, (Final Report), BAPPEDA, Palembang.

Brenda and Vale, R. (1991), Green Architecture Design For Sustainable Future, $<$ http://www.w3.directory.com/directory-Science-and-technology-of-art.php>.

Brown, G. Z. and DeKay, M. (2001), Sun, Win \& Light, Architectural Design Strategies, second edition, John Wiley \& Sons, Inc, New York, ChichesterWeinheim, Brisbane, Singapore, Toronto. ISBN 0-471-34877-5 (pbk: alk. paper).

Carrow, R. (1995), Danforth Air Filtration \& Air Purification, Buffalo, NY, <https://www.danforthfilters.com/secure/store/Air-Filters-Museum-1.asp> (Accessed on 21 Agustus 2013).

Craven, J. (2003), What Is Green Architecture and Green Design?,<http://architecture.about.com/od/greenconcepts/g/green.htm>.

Echols,J. M. (2000), An English-Indonesian Dictionary,XXIV edition, PT. Gramedia Jakarta, Jakarta.

Energy Efficiency and Renewable Energy (), Passive Solar Design, <http://www.eere.energy.gov/de/passive_solar_design.html>.

Florida International University (2013), Green Architecture, <http://www2.fiu.edu/$\sim$ readg/Courses/ArchTheory/-GreenStrategies.pdf >.

Hanum, M. and Murod, C. (2012), Energy Efficiency Concept of GreenArchitecture: Improving Imagination of Comprehensive, Dinamic, Innovative and $\mathrm{Fu}-$ turistic Architecture Design, Added Value of Energy Resources (AvoER), 73, 28-29 November, Gedung Serba Guna Paska Sarjana Universitas Sriwijaya, Palembang.

Hill, McG. (2003), McGraw-Hill Dictionary of Architecture and Construction: Green Architecture, <http://encyclopedia2.the free dictionary.com/green+architecture>.

Krishan, A. and Nick, B. (2001), Climate Responsive Architecture, A Design Handbook for Energy Efficient Buildings, Tata McGraw-Hill Publishing Company Limited, 7 West Patel Nagar, New Delhi 110 008, typeset at ANVI Composer, A1/33 Pashchim Vihar, New Delhi 110063 and printed at Gopson Papers Limited A-28, Sector IX, Noida. ISBN 0-07-453218-3.

Mandeep, J.S. and Nalinggam,R. (2011), Scientific Research andEssays,6(2), 447452, 18 Jan 2011, <http://www.academicjournals.org/SREDOI:10.5897/SRE10.971>.

Roy, MS. M. (2001),5 Importance of Green Architecture Today, <www.sarienergy.org/..../greenarchitecture,madhumita-roy-pdf-d514666507>.

Surya Urza (2013),Active and Passive Solar Energy, <http://suryaurza.com/blog/2013/05/13/active-and-passive-solar-energy/>.

Surya Urza (2013), Active and Passive Solar Energy, <http://suryaurza.com/wpcontent/up-loads/2013/05/92841413.jpg/active-and-passive-solar-energy/>.

WBDG ( ), Whole Building Design Guide, <http://www.wbdg.org/design/libraries.php>. 
Webster, E. (2008), Solar Energy: Active or Passive?,<http://www.greenerlivingtoday.com/solar-energy-active-or-passive/>.

Wikipedia (2013), Passive solar building design, <http://en.wikipedia.org/wiki/Passive_solar\#The_solar_path_in_passive_design>.

Wines, J. (2008), Green Architecture, P. J. [ed], TASCHEN GmbH, Hohenzollernring 53, D-50672 Koln, www.taschen.com, China, ISBN 978-3-8365-0321-1. 